\title{
REFORMASI PENDIDIKAN ISLAM: Tinjauan Pembelajaran Pendidikan Islam dengan Pendekatan Kurikulum Sosial Kultural
}

\section{Imas Muchofillah}

UIN Sunan Gunung Djati Bandung DPK di STAI Fatahillah Serpong Tangerang Selatan

\begin{abstract}
Islamic Education system is currently experiencing saturated management. One of that cause is many theories that is given in Islamic Education system we must include of cultural values in order to the Islamic Education system is more enthusiastic. Because after Islam will continue to cling to the existing culture of the local community. The way to reform and reformulate a new paradigm of learning strategies that balance. By learning the balance between the cognitive (intellectual ability), affective (spiritual abilities) and psychomotor (professional abilities).

Human potential as God's gift should be developed, while the development potential in accordance with the instructions of the Lord is worship. Thus, the purpose of human events in the context of worship is in terms of the development of human potential that made him achieve the highest degree of humanity. And the bigh degree of humanity would look if useful to others. Because rabmatan lil'alamin in the concept of Islam is regardless of tribe, race, religion, race and class.
\end{abstract}

Keywords: Reform education system, learning strategy, cultural values

\section{PENDAHULUAN}

Kemajuan ilmu pengetahuan dan teknologi di bidang transformasi dan informasi menjadikan belahan dunia semakin modern dan global. Akibatnya hampir tidak ada relung-relung kehidupan yang belum tersentuh modernitas, termasuk aspek kehidupan keagamaan. Di kalangan masyarakat modern tertentu, agama bukan saja tidak diamalkan dalam kehidupan praktis, tetapi juga ditinggalkan. Dengan kemajuan ilmu pengetahuan dan teknologi, seperti Eropa, mungkin juga di Indonesia, masyarakat menjauh dari agama. Bahkan telah membebaskan manusia dari serba Tuhan.

Masyarakat sekarang dan yang akan datang merupakan masyarakat ilmiah dan modern, yang berlebihan menggunakan ilmu pengetahuan dan teknologi yang rancang bangunnya berlandaskan kebenaran positivistic, rasionalistik dan 
phenol-monologik, yang semuanya serba probabilistic. Dalam masyarakat ilmiah, segala sesuatu yang tidak dapat dijangkau oleh akal dianggap nihil. Bahkan masyaratak barat sampai tahap yang lebih ekstrem berupa sekularisme, agnotisme, babkan atheisme, seolah-olah Tuhan telah tiada.

Pada saat ini hegemoni peradaban dunia berada di pundak mereka. Namun pada sisi lain, sekulerisme itu juga menjerumuskan ummat manusia pada kenestapaan, kegersangan spiritual, kekejaman intelektual, kekerasan struktural, kehancuran lingkungan menghadapi polusi dan dehumanisasi (kehilangan nilai). Berbagai manfaat dari kemajuan ilmu pengetahuan dan teknologi tetapi sering menjadi konsumeristis dan semakin serakah. Dengan demikian timbulah persoalan.

Posistivistik, ialah sesuatu yang dilakukan dengan tegas. Probabilistic ialah kemungkinan sesuatu hal untuk terjadi. Rasionalistik adalah bersifat menggunakan akal. Kurikulum adalah rencana pembelajaran yang akan disampaikan kepada anak didik. Sekulersime adalah paham pemisahan antara urusan agama dengan urusan kehidupan manusia. Agnotisme adalah suatu anggapan mustahil untuk membuktikan ada atau tidak adanya Tuhan. Atheisme adalah paham tidak percaya adanya Tuhan. Empirik adalah tindakan yang dilakukan dengan penghayatan. Hedonistic ialah pemaknaan sesuatu dengan ukuran kelezatan atau kenikmatan.

Selama ini bangsa kita terlampau jauh mengadopsi sistem dan metode pendidikan yang lahir dan berkembang di luar negeri serta mengabaikan nilai-nilai kearifan lokal yang ada di dalam negeri sendiri. Sehingga kepribadian bangsa lambat laun mengalami penurunan yang berujung kepada hilangnya jati diri bangsa yang telah diwariskan secara turun temurun.

Sebenarnya kita memiliki Ribuan budaya, yang masing-masing memiliki ciri khas, dan belum terserap menjadi bagian dalam sistem Kependidikan Nasional. Inilah yang harus digali oleh para peneliti dan ahli, khususnya dalam bidang pendidikan.

\section{KONTEKSTUAL ISLAM DALAM MASYARAKAT}

Masyarakat ilmiah saat ini adalah masyarakat yang menggunakan ilmu pengetahuan dan teknologi yang bersumber dari kajian rasional, dengan dampaknya pada perubahan perilaku masyarakat. Seiring dengan sosialisasi ilmu pengetahuan dan teknologi termasuk juga sosialisasi nilai dan budaya, bahkan ideologi tertentu merisaukan para ahli pendidikan Islam. Pengalihan ilmu pengetahuan teknologi dari barat secara tidak langsung berarti pengalihan dua unsur budayanya. Hal itulah menurut Harun Nasution disebut modernisasi dalam masyarakat. ${ }^{1}$

${ }^{1}$ Harun Nasution menyatakan bahwa modernisasi dalam masyarakat barat mengandung 
Informasi yang diterima tidak pernah netral. Dalam konteks itu sudah terkandung nilai-nilai, missi dan pandangan hidup. Informasi selalu merupakan perumusan realitas dan perspektif tertentu. Informasi adalah formulasi. ${ }^{2}$ Keadaan masyarakat pada zaman penggunaan ilmu pengetahuan dan teknologi sebagai basis kehidupannya, tidak hanya digantikan oleh energi mesin, bahkan cara pikir manusia, telah ganti jalan pola mesin, sementara realitas kehidupan semakin dikendalikan oleh materialisme hedonistic. Akibatnya tiada lain hanya berkisar pada to have more and to use more. Lebih jauh Mudji Sutrisno menggambarkan masyarakat ilmiah dan teknologi, bahwa dunia ilmu pengetahuan dan teknologi memberi banyak kemudahan di samping ada sisi negatifnya. Sisi negatifnya antara lain: pertama, kecenderungan modernisme itu untuk massifikasi, penyeragaman manusia dalam kerangka teknis, sistem industri yang menempatkan semua orang sebagai mesin atau "sekrup" dari sebuah sistem teknis rasional. Kedua, sekulerisme yang berarti tidak diakuinya lagi adanya ruang nafas buat dimensi religius dalam hidup kita. Ketiga, orientasi nilainya yang menomorsatukan jalan pintas, resep jawaban tepat, cepat, langsung. ${ }^{3}$

Persoalannya menjadi kompleks, karena banyak penawaran pilihan menyangkut norma dan standar kebenaran. Keliru dalam pemilihan standar kebenaran, menjadikan manusia didominasi oleh penalaran kemanusiaan yang terlampau jauh, sehingga orientasi spiritual transcendental telah terbabat habis dan diganti budaya materialistic atheistic.

Dalam makna teks Islam datang untuk membawa manusia meraih kebahagiaan lahir bathin, dunia akhirat ${ }^{4}$ dan menjadi rahmat (kesejahteraan) bagi seluruh sekalian alam. ${ }^{5}$ Dalam hubungan ini Fazlur Rahman berkomentar, bahwa Al-quran bukanlah untuk Tuhan tetapi untuk kepentingan manusia yang mempunyai relevansi. ${ }^{6}$ Untuk menjadikan ajaran Islam eternal, rahmat, kebahagiaan universal, dunia akhirat, agama fitrah, memiliki daya adaptif tinggi, mau tidak mau di samping reformulasi-reformulasi pemahaman terhadap teks

fikiran, aliran, gerakan dan usaha-usaha menambah faham-faham, adapt-istiadat, instistusiinstitusi lama untuk disesuaikan dengan suasana baru yang ditimbulkan oleh kemajuan ilmu pengetahuan dan teknologi. Harun Nasution, 1987, Pembaharuan Dalam Islam. UI Press Jakarta, hal. 157.

${ }^{2} J a l a l u d d i n$ Rakhmat. 1992. Islam Aktual. Mizan, Bandung, hal. 74.

${ }^{3}$ Mudji Sutrisno SJ. 1994. Dialog Kritis dan Identitas Agama. Mizan Bandung, hal. 178.

${ }^{4} \mathrm{Al}-$ Quran surat Al-Baqoroh, ayat 201 dan Al- Qoshos, ayat 77.

${ }^{5} \mathrm{Al}$-Quran surat Al-Anbiya ayat 107.

${ }^{6}$ Fazlur Rahman. 1983. Tema Pokok Al-Quran. Penerjemah Anas Mahyuddin. Pustaka Jakarta, hal. 58. 
juga harus didukung pengkajian nyata, agar segala aktivitas manusia itu lebih bermutu, efektif dan efisien serta bersifat sosiologis.

Isyarat untuk kerangka tersebut disebutkan oleh al-quran bahwa bekerja menurut tabi'atnya (profesionalismenya). ${ }^{7}$ Untuk mendukung ke-eternalan dan keuniversalan serta kesejahteraan ajaran Islam, sehingga diterima oleh ummat manusia yang sehat, kita harus melihat Islam itu mempunyai karakteristik yang fleksibel. Menurut Yusuf Qardawi, Islam mempunyai karakteristik yaitu Robbaniyab (ketuhanan), insyaniyab (kemanusiaan), syumul (universal) untuk semua zaman, tempat dan manusia, al-wasthiyyah (pola keseimbangan atau keadilan), al-wadi'iyah (kontekstualo), al-wudbub (kejelasan) dan integrasi antara tsabat (konsisten) dan murunab (luwes). ${ }^{8}$

Khusus dalam hal al-waqi'iyah berpijak pada kenyataan objektif manusia persoalan universalisme Islam dapat dipahami secara lebih jelas, termasuk dalam hal reformasi pendidikan. Al-quran memperkenalkan dirinya sebagai agama yang sesuai dengan fitrah manusia. ${ }^{9}$ Fitrah (naluri kemanusiaan) sesuatu yang dimiliki oleh setiap orang, maka itu berarti al-quran mengklaim, ajarannya sesuai dengan seluruh manusia. Hanya saja, di sisi lain ada pula kenyataan perbedaan yang diakibatkan lingkungan sosial budaya maupun oleh kodrat masing-masing pribadi manusia.

Dua kenyataan objektif diatas memberi gambaran bahwa al-quran bersifat universal berpijak pada kesamaan manusia, partikular dan kondisional akibat perbedaan manusiawi. Yusuf Qardawi menyebutkan ciri ini dengan fleksibelitas $^{10}$ sepanjang menyangkut persoalan yang prinsipil, Islam mempunyai pendirian yang teguh, tetapi di dalam persoalan Furu', khususnya strategi pembelajaran agama Islam ia justru fleksibel. Konteksnya tercermin dari prinsip yang memberi peluang untuk tidak melaksanakan petunjuk-petunjuk, apabila pelaksanaannya terganggu salah satu aspek pemeliharaan kehormatan agama, jiwa, akal, keturunan dan harta, ${ }^{11}$ prinsip dan nilai itu bersifat universal sedang penjabarannya bersifat partikular. Islam dalam menghadapi perbedaanperbedaan, lebih mementingkan isi dan makna dibandingkan dengan bentuk formalnya. Untuk itulah disamping ajaran al-quran dipahami secara tekstual, tetapi juga harus dikaitkan dengan konteksnya.

${ }^{7}$ Al-quran surat Al-Isra' ayat 83.

${ }^{8}$ Yusuf Qardawi. 1983. al-khashaaish al-ammah li al-islam. Muassasah al-risalah, Beirut, hal. Vii.

${ }^{9} \mathrm{Al}$-quran surat Al-Ruum ayat 3.

${ }^{10}$ Yusuf Qardawi. 1990. Syari'at Islam di Tantang Zaman. Penerjemah Abu Zaky. Pustaka Progressive, Surabaya, hal. 19.

${ }^{11} \mathrm{Al}$-quran surat $\mathrm{Al}$-Baqoroh ayat 180. 
Dalam reformasi pendidikan Islam haruslah didasarkan pada al-quran dan assunnah. Memberikan penghormatan kepada akal manusia, bimbingan ilmiah, tidak menentang fitrah, serta memeliharan tuntutan sosial yang berdasarkan pada nilainilai al-quran dan as-sunnah. Atas prinsip maslahat dan menjauhkan kemudharatan, sehingga pendidikan Islam diletakkan di dalam kerangka sosiologis, karena menurut Azyumardi Azra, dasar pendidikan Islam ialah warisan pemikiran Islam, seperti hasil pemikiran para ulama, filosof, cendikiawan muslim yang pemikiran mereka merupakan refleksi terhadap ajaran-ajaran pokok Islam. ${ }^{12}$

\section{STRATEGI PEMBELAJARAN AGAMA ISLAM}

Menyadari berbagai karakteristik mentalitas masyarakat sebagai dampak dan kemajuan ilmu pengetahuan dan teknologi, persoalan pendidikan Islam semakin kompleks dan rumit. Pendidikan Islam dewasa ini menghadapi beberapa problem berat, antara lain; pertama, adanya inefisiensi internal yang berupa tingginya angka putus sekolah (drop out), kedua, terjadinya inefisiensi eksternal berupa tidak dipakainya keluaran pendidikan Islam pada pasar tenaga kerja. Kalaupun dipakai, pekerjaan itu berbeda dengan pendidikan yang diperoleh di bangku kuliah (mismatch), ketiga, krisis etika dan moral sebagai akibat dari kurang efektifnya proses sosialisasi sikap-sikap dan nilai-nilai agama dalam proses pembelajaran.

Asumsi-asumsi yang menyatakan kerusakan moral sosial yang terjadi bukanlah tanggung jawab para pendidik agama secara langsung. Tetapi sejauhmana semua itu juga ada keterkaitan dengan pola strategi pembelajaran agama yang selama ini berjalan secara konvensional-tradisional dan materi pendidikan tumpang tindih menjenuhkan peserta didik.

Untuk menjawab persoalan diatas, terutama inefisiensi eksternal dan krisis etika dan moral adalah antara lain dengan cara reformasi dan mereformulasi paradigma baru tentang instructional strategi (strategi pembelajaran). Strategi pembelajaran atau course design (desain pembelajaran) menurut Lynn dan Alenoush mencakup empat hal yaitu content (materi), learning objective (tujuan belajar), instructional strategi (metode pembelajaran) dan evaluation. ${ }^{13}$

Sebelum bicara masalah strategi pembelajaran, perlu disinggung mengenai asumsi pendidik dalam proses pembelajaran. Pertanyaannya, apakah kualitas pribadi hamba Allah yang selalu bertaqwa kepada-Nya dan memperoleh

${ }^{12}$ Azyumardi Azra. 1999. Pendidikan Islam, Tradisi dan Modernisasi Menuju Milenium Baru. Logos Wacana Ilmu, Jakarta, hal, 9.

${ }^{13}$ Hamruni. 1999. Strategi Pembelajaran di Perguruan Tinggi (teknik mengaktifkan kelas). Makalah workshop pendidikan dosen IAIN SUKA, jogjakarta, hal. 4. 
kebahagiaan dunia akhirat, sebagai hasil dari proses pendidikan Islamkah atau merupakan Inayyahtullah (tangan pemeliharaan Allah) ?. Kualitas iman khulafa' al-rasyidin, shalihah istri Fir'aun, keteguhan imam bilal (sahabat rasullulah) sebagai hasil proses pendidikan ataukah sebagai Innayatullab? tentu jawabannya sangat rumit. Namun paling tidak membuka kesempatan bagi para pakar pendidikan Islam membangun paradigma baru dalam rangka merumuskan desain pembelajaran. Kalau kepribadian manusia ditentukan ikhtiar manusia tetapi juga ditentukan secara akhir oleh qudrab iradab Tuhan, berarti manusia dalam proses pembelajaran tetpa dalam rangka pengawasan moral dan ibadah. Sehingga selain manusia aktif membimbing anak didik, juga harus selalu taqarrub kepada Allah dan menjadikan Nabi Muhammad Saw sebagai teladan.

Teori hukum tentang konsep dasar moral manusia dan aksinya terhadap dunia luar telah banyak dibicarakan oleh ahli pendidikan seperti hukum goodactive, bad-active, neutral-passive, neutral-interactive, ${ }^{14}$ kemudian berkembang menjadi teori empiris, dan konvergensi. Dalam teori konvergensi nampaknya belum dapat mencakup kekenyalan kebertuhanan kita. Karena wilayah konvergensi terbatas pada sunnatullah dan belum menyentuh inayatullah. Ini sejalan dengan pendapat M Quraish Shihab, bahwa setiap muslim pencaya sepenuhnya bahwa tata kerja alam raya berjalan konsisten sesuai dengan hukum-hukum yang ditetapkan oleh Allah, tetapi pada saat yang berbeda tidak tertutup kemungkinan terjadinya peristiwa-peristiwa yang berbeda dengan kebiasaan-kebiasaan yang dilihatnya sehari-hari, karena baik yang terlihat seharihari maupun yang tidak biasa terlihat, keduanya sama ajaib dan mengagumkan.

Banyak peristiwa masa kini dinilai "biasa" oleh orang saat ini, juga kejadian yang sama dinilai luar biasa oleh generasi terdahulu, ${ }^{15}$ maka hukum itu dapat bermakna dan aktual dari dua jalan. Pertama, dengan jalan hukumhukum yang telah dikenal oleh manusia (sunnatullah), dan kedua, dengan jalan inayatullah, sehingga paradigmanya menjadi "good active-responsifinayatullah". Ini sejalan dengan jaminan Allah pada kita untuk meminta kepadaNya dan akan dikabulkan. ${ }^{16}$

Dengan berpegang kepada paradigma di atas, maka dalam mentransformasikan pendidikan Islam harus tetap semuanya dalam kerangka

\footnotetext{
${ }^{14}$ Menurut Morris L. Bigge, bahwa sifat dasar moral manusia dan aksinya terhadap dunia luar bermacam-macam. Seperti sifat dasar moral manusia itu jelek, baik dan netral (tidak baik dan tidak pula jelek). Sedangkan aksinya terhadap dunia luar terdiri dari; aktif, pasif dan interaktif. Keterangan selanjutnya dapata dibaca pada Morris L. Bigge. 1982. learning Theories for Teacher. Publisher, inc, USA, hal. 16-18.

${ }^{15}$ M. Quraish Shihab. 1997. Mu'jizat al-Quran. Mizan bandung, hal. 21-22.

${ }^{16} \mathrm{Al}$-quran surat al-Mukminun ayat 60. 
sejalan dengan sunatullah dan pengharapan Inayatullah. Dari paradigma ini dapat di pahami bagaimana ketatnya para ahli pendidikan Islam dalam menentukan etika peserta didik dan pendidik, seperti yang diungkapkan oleh Al-Ghazali, ${ }^{17}$ Ibnu Taimiyah, ${ }^{18}$ dan Athiyah al-Abrasyi. ${ }^{19}$

Dalam pandangan Islam, manusia adalah makhluk Allah paling mulia dan sempurna. Ia makhluk yang terdiri dari jiwa dan raga. Ia makhluk rasional semacam hati (qolb), intelek (aql), dan kemampuan-kemampuan fisik, intelektual, pandangan kerohanian, pengalaman, kesadaran dan hawa nafsu kebinatangan atau istilah lain sekalipun tidak mencakup-kognitif, afektif dan motorik dengan berbagai potensi dengan potensi ini manusia dapat menyempurnakan kemanusiaannya menjadi pribadi yang ahsan taqwim (sebaik-baik ciptaan Tuhan). Sebaliknya ia dapat pula menjadi makhluk yang paling hina karena dibawa kepada kecenderungan kebinatangan dan kebodohannya. ${ }^{20}$

Untuk itu strategi pembelajaran terhadap pembentukan cognitive domain, affective domain dan psychomotor domain tetap dalam kerangka menciptakan manusia yang berpribadi Muslim dengan optimalisasi intelektual, spiritual, dan keterampilan dengan standar-standar yang jelas, sehingga dapat di evaluasi. Dari tujuan umum pendidikan Islam kemudian dirumuskan learning objective lengkap dengan tahap-tahap penguasaan anak. Dari tiga ranah tahapan, kemudian dapat dicapai learning objectif yang terperinci lengkap dengan pengorganisasian materi, metode yang qurani, ${ }^{21}$ media dan sistem evaluasi yang jelas.

${ }^{17} \mathrm{Al}-\mathrm{Ghazali}$ mensyaratkan pendidikan itu antara lain ia harus memiliki hati ikhlas, mencari keridhaan Tuhan dalam tugasnya, jujur, terpercaya. Fatiyah Sulaiman. 1964. Madzaahib fi al-Tarbiyah Bahts fi al-Madzaahib al-Tarbawy Inda al-Ghazali'i. Maktabah Nadlah, Kairo mesir, hal. 33-38.

${ }^{18}$ Ibnu Taimiyah menempatkan pendidik sebagai ulama pewaris Nabi SAW, sebagai uswatun hasanah. Majid Irsan al-Kailani. 1986. Alfikr al-Tarbawy Inda Ibnu Taimiyah. Maktabah Dar al-Turas, Madinah, hal. 177-178.

${ }^{19}$ Athiyah al-Abrasyi berpendapat bahwa etika peserta didik antara lain, ia mencari ilmu dengan hati yang suci, mendekatkan diri kepada Allah, menghormati guru karena Allah dan bekerja atas ridhoNya. Muhammad Athiyah al-Abrasyi. 1975. At-Tarbiyah al-Islamiyah wa Falaasifatuhu. 'Ia al-Babi al-Halabi, wa Syurakah, Mesir, hal. 143-144.

${ }^{20} \mathrm{Al}$-Quran surat al-Tiin ayat 4-5.

${ }^{21}$ Menurut al-Nahlawi, metode pendidikan Quran yang dapat menerima petunjuk Ilahi dan mengokohkan kedudukan manusia di dunia ialah metode hiwar (hiwar) qurani dan Nabawi, kisah-kisah qurani dan nabawi, amtsal (perumpamaan) qurani dan Nabawi, keteladanan, pembiasaan dan pengalaman, ibrah (pelajaran) dan mauidhah (peringatan), dan targhib (membuat senang) dan tarhib (membuat takut), baca. Nahlawi Abdurrahman. 1989. Prinsip-Prinsip dan Metode Pendidikan Islam. Penerjemah Herry Noer Ali. Diponegoro, Bandung, hal, 283-284. 
Proses pembelajaran selama ini lebih menitik beratkan pada ranah kognitif, sedikit menyentuh ranah afektif, tetapi tidak jelas teknik evaluasinya. Ini terlihat pada bentuk-bentuk soal pada pendidikan Islam. Padahal seharusnya proses pembelajaran dapat mengubah kemampuan intelektual menjadi makna dan nilai yang terinternalisasi dalam diri peserta didik, lewat berbagai strategi pembelajaran menggugah anak didik berekspresi. Kemudian makna dan nilai yang sudah menjadi pribadinya dapat menjadi sumber motivasi bergerak maju berbuat (motorik) secara konkret dalam kehidupan sehari-hari, makna dan nilai itu sekaligus menjadi filter segala bentuk kejahatan.

Optimalisasi seimbang antara intelektual, spiritual dan keterampilan professional peserta didik punya daya tahan untuk merespon setiap permasalahan yang muncul serta mengambil alternatif solusi terhadap permasalahan-permasalahan tersebut sehingga terpadunya pembinaan rohani dengan penyesuaian diri dengan perubahan sosial. Untuk itu penciptaan lingkungan yang dapat berekspresi (baik yang alami maupun yang direkayasa) perlu disajikan sedemikian rupa, sehingga menemukan dan menyadari makna kehidupan dan pengalaman kebertuhanan.

Menyangkut persoalan content selain terhadap ajaran-ajaran yang sifatnya ritual, maka harus dikembangkan dan dikontekstualisasikan. Pada garis besarnya pendidikan keagamaan terdiri dari iman, Islam dan Ihsan, namun strategi pembelajaran perlu dirancang sehingga tidak jenuh mempelajarinya. Menurut Fazlur Rahman bahwa kemunduran kualitas ilmu pengetahuan Islam adalah kekeringan yang gradual dari ilmu-ilmu keagamaan karena pengucilannya dari kehidupan intelektualisme awam yang juga kemudian mati, pelarangan ulama zaman pertengahan dalam mencari ilmu yang tidak langsung berhubungan dengan amal, dan ilmu adalah sesuatu yang harus diterima (acquired kasb) bukan sesuatu yang dicari dan dibangun secara sistematis oleh akal pikiran oleh akal pikiran manusia sendiri. ${ }^{22}$

Menurut Amin Abdullah yang dikutip oleh Abdul Munir Mulkan, mengenai prinsip-prinsip keberagamaan Islam, perlu didekati secara doktriner, sementara wilayah kedua perlu didekati secara saintifik, ${ }^{23}$ maka paradigma materi pembelajaran diatur porsi ranahnya sesuai dengan perkembangan jiwa anak.

Untuk mengoptimalkan strategi pembelajaran tersebut yang mencakup tiga ranah dimaksud didukung oleh lembaga pendidikan Islam yang serius menangani mutu akademik dan profesionalisme. Bagi Muchtar Buchori,

${ }^{22}$ Fazlur Rahman. 1983. Islam. Penerjemah Ahsin Muhammad, Pustaka, bandung, hal, 270-272.

${ }^{23}$ Abdul Munir Mulkan, et al. 1998. Religius Iptek, Pustaka Pelajar, jogjakarta, hal. 63. 
academik, antara lain bermakna 1) yang bersifat serba teoritis, bukan yang bersifat praktis, 2) berhubungan dengan kajian yang bersifat melebarkan dan memperdalam wawasan, dan bukan dengan kajian yang bersifat teknis atau vokasional, dan 3) sangat ilmiah, sehingga nampak kurang berhubungan dengan kenyataan-kenyataan yang terdapat dalam kehidupan sehari-hari. Kriteria yang dapat dipergunakan untuk mengukur mutu akademik antara lain ialah ketabahan, ketekunan, dan ketuntasan dalam melaksanakan kegiatankegiatan untuk memajukan ilmu pengetahuan dan kemanusiaan, sambil menjunjung tinggi kebebasan akademik, yaitu kebebasan untuk mempelajari dan mengajarkan pengetahuan yang relevan. ${ }^{24}$

Sulit rasanya mencapai optimalisasi kemampuan intelektual, komitmen spiritual dan professional, kalau tidak menciptakan strategi pembelajaran yang kondusif. Maka dengan mutu akademik, kerja yang mumpuni, pendidikan Islam dapat dirancang bangun menjadi sebuah institusi yang berprospek di masa depan dan ini sekaligus menjawab persoalan external inefisiency. Kompleksitas keadaan seperti diatas akan dapat menciptakan program pendidikan yang tidak hanya melatih kemampuan spiritual, dan intelektual tetapi juga diorientasikan kepada outcome (keluaran) sebagai calon man power (tenaga kerja) dan buman resources (sumberdaya manusia) yang berkualitas. Konsekuensinya content pendidikan Islam harus disertakan dalam kerangka sosiologis (tuntutan sosial), tuntutan ilmu pengetahuan dan teknologi dan kebutuhan tenaga kerja serta tuntutan spiritual yang handal.

\section{KESIMPULAN}

Dari gambaran di atas, maka reformasi pendidikan Islam pada saat ini merupakan suatu keharusan terutama dalam bidang strategi pembelajaran agama Islam. Tentu reformasi tersebut harus di dukung oleh lembaga pendidikan yang mumpuni. Dengan demikian akan mudah menciptakan proses pembelajaran yang seimbang antara ranah kognitif (kemampuan intelektual), afektif (kemampuan spiritual) dan psikomotorik (kemampuan professional). Outcome nya menjadi man power dan buman resources yang berkualitas tinggi yang berilmu amaliyah dan amal ilmiyah sekaligus mampu mengatasi berbagai persoalan.

Dalam hal ini dinyatakan bahwa potensi manusia sebagai karunia Tuhan haruslah dikembangkan, sedangkan pengembangan potensi yang sesuai dengan petunjuk Tuhan merupakan Ibadah. Jadi, tujuan kejadian manusia dalam rangka ibadah adalah dalam pengertian pengembangan potensi-potensi manusia

${ }^{24}$ Muchtar Buchori,et al. 1998. Pendidikan Dalam Pembangunan. Tiara Wacana, jogjakarta, hal. 34-35. 
sehingga menjadikan dirinya mencapai derajat kemanusiaan yang tinggi. Derajat ini dicapai dengan mengaktualisasikan segala potensi yang dikaruniakan Tuhan Kepadanya.

\section{DAFTAR PUSTAKA}

Harun Nasution. 1987. Pembaharuan Dalam Islam. UI Press Jakarta.

Jalaluddin Rakhmat. 1992. Islam Aktual. Mizan, Bandung.

Mudji Sutrisno SJ. 1994. Dialog Kritis dan Identitas Agama. Mizan Bandung.

Fazlur Rahman. 1983. Tema Pokok Al-Quran. Penerjemah Anas Mahyuddin. Pustaka Jakarta.

Yusuf Qardawi. 1983. al-khashaaish al-ammah li al-islam. Muassasah al-risalah, Beirut.

Yusuf Qardawi. 1990. Syari'at Islam di Tantang Zaman. Penerjemah Abu Zaky. Pustaka Progressive, Surabaya.

Azyumardi Azra. 1999. Pendidikan Islam, Tradisi dan Modernisasi Menuju Milenium Baru. Logos Wacana Ilmu, Jakarta.

Hamruni. 1999. Strategi Pembelajaran di Perguruan Tinggi (teknik mengaktifkan kelas). Makalah workshop pendidikan dosen IAIN SUKA, jogjakarta.

Morris L. Bigge. 1982. Learning Theories for Teacher. Publisher, inc, USA.

M. Quraish Shihab. 1997. Mu'jizat al-Quran. Mizan Bandung.

Fatiyah Sulaiman. 1964. Madzaahib fi al-Tarbiyah Babts fi al-Madzaabib alTarbawy Inda al-Ghazali'i. Maktabah Nadlah, Kairo Mesir.

Majid Irsan al-Kailani. 1986. Alfikr al-Tarbazey Inda Ibnu Taimiyah. Maktabah Dar al-Turas, Madinah.

Muhammad Athiyah al-Abrasyi. 1975. At-Tarbiyah al-Islamiyah wa Falaasifatubu. 'Ia al-Babi al-Halabi, wa Syurakah, Mesir.

Nahlawi Abdurrahman. 1989. Prinsip-Prinsip dan Metode Pendidikan Islam. Penerjemah Herry Noer Ali. Diponegoro, Bandung.

Fazlur Rahman. 1983. Islam. Penerjemah Ahsin Muhammad, Pustaka, Bandung.

Abdul Munir Mulkan, et al. 1998. Religius Iptek, Pustaka Pelajar, Jogjakarta.

Muchtar Buchori, et al. 1998. Pendidikan Dalam Pembangunan. Tiara Wacana, Jogjakarta. 